\title{
Pola Pembangunan Masyarakat Desa Miskin Pesisir Pantai Dalam Mempertahankan Kelangsungan Hidup
}

\author{
Hamim Farhan \\ Aslich Maulana \\ Universitas Muhammadiyah Gresik Jl. Sumatra 101 GKB Gresik \\ hamim.farhan@gmail.com
}

\begin{abstract}
Abstrak
Mengkaji masyarakat nelayan merupakan persoalan yang khas dan bukan persoalan yang mudah, yang sekaligus perlu mendapatkan perhatian serius. Sosiologi masyarakat pesisir menjadi penting ; daerah pantai yang panas, pemukiman nelayan yang padat dan sesak, temperatnen masyarakatnya yang dianggap "keras" serta sederet kecirian yang khas lainnya menjadi menarik secara sosiologis untuk diungkap. Oleh karena itu untuk mewujudkan relevansi pola pembangunan pun perlu memperhatikan berbagai aspek dan karakteristik masyarakat nelayan itu sendiri. Dalam pendekatan sosiologi misalnya, masyarakat pesisir berbeda dengan masyarakat pertanian yang basis kegiatannya di darat. Hal ini disebabkan sosiologi masyarakat pesisir direkonstruksi dari basis sumber daya resourses, sedangkan sosiologi pedesaan berbasis pada society. Sehingga pendekatannya pun harus berbeda, begitu juga pendekatan pola pembangunannya.

Penelitian ini bertujuan mendapatkan gambaran yang jelas tentang sistem pola/model pembangunan dan nilai institusi sosial yang relevan untuk mempertahankan kelangsungan hidup dan meningkatkan kesejahteraan masyarakat miskin pesisir pantai Desa Weru, Paciran dan Blimbing di wilayah Kabupaten Lamongan.

Kesulitan meningkatkan kesejahteraan kominitas desa pantai, selain dipengaruhi faktor internal, juga karena pengaruh faktor eksternal. Keterbatasan pendidikan kurangnya kesempatan mengakses dan menguasai teknologi yang modern dan tidak dimilikinya modal cukup adalah faktor-faktor internal yang sering menyulitkan usahausaha memberdayakan kehidupan para nelayan. Disisi lain, sejumlah faktor eksternal, seperti makin terbatasanya potensi sumberdaya laut yang bisa dimanfaatkan nelayan, persaingan yang makin intensif, mekanisme pasar, posisi tawar nelayan dihadapan tengkulak keadaan infrastruktur pelabuhan perikanan, dan yurisdiksi daerah otonomi adalah beban tambahan yang makin memperparah tekanan kkemiskinan yang dihadapi masyrakat desa pesisir.

Untuk itu perlunya mengubah paradigma program pemberdayaan masyarakat pesisir dari orientasi pada peningkatan hasil produksi ke pola baru pada efisiensi proses produksi dan upaya pengembangan deversifikasi usaha. meningkatkan posisi barganing
\end{abstract}


Serta menhindari tumbuhnya ketergantungan dengan mengoptomalkan potensi desa melalui lembaga ekonomi sosial/asuransi sosial desa dan lainnya.

Kata Kunci: Pola Pembangunan, Nelayan, Kemiskinan

\section{Pendahuluan}

Minimal ada tiga pertimbangan mengapa kajian penelitian ini perlu dilakukan. Pertama, secara kuantitatif kajian tentang masyarakat nelayan atau masyarakat pesisir masih sangat terbatas (langka) jika dibandingkan dengan penelitian masyarakat petani atau masyarakat perkotaan. Kajian terhadap masyarakat pesisir pantai ini sangat berarti untuk kepentingan pembangunan manusia, karena masyarakat nelayan merupakan masyarakat yang tergolong miskin dibandingkan dengan kelompok masyarakat lainnya (the poorest of the poor).

Kedua, kelangkaan kajian penelitian terhadap masyarakat nelayan ini sangat tidak seimbang jika dikaitkan dengan Negara Indonesia ini sebagai negara maritim yang terbesar di dunia. Dari segi akademis kita kalah jauh dengan kuantitas dan kualitas kajian serupa di Filipina dan Thailan. Kelangkaan ini mencerminkan lemahnya perhatian kita di bidang kemaritiman (Ocean Policy) sehingga menjadi wajar jika pembangunan sektor kemaritiman nasional tertinggal dibanding dengan kedua negara ASEAN tersebut. ${ }^{1}$

Ketiga, mengkaji masyarakat nelayan merupakan persoalan yang khas dan bukan persoalan yang mudah, yang sekaligus perlu mendapatkan perhatian serius. Sosiologi masyarakat pesisir menjadi penting ; daerah pantai yang panas, pemukiman nelayan yang padat dan sesak, temperatnen masyarakatnya yang dianggap "keras" serta sederet kecirian yang khas lainnya menjadi tnenarik secara sosiologis untuk diungkap. Oleh karena itu untuk mewujudkan relevansi pola pembangunan pun perlu memperhatikan berbagai aspek dan karakteristik masyarakat nelayan itu sendiri. Dalam pendekatan sosiologi misalnya, masyarakat pesisir berbeda dengan masyarakat pertanian yang basis kegiatannya di darat. Hal ini disebabkan sosiologi masyarakat pesisir direkonstruksi dari basis sumber daya resourses, sedangkan sosiologi pedesaan berbasis pada society.

\footnotetext{
${ }^{1}$ Kompas, 17 Mei 2003
} 
Sehingga pendekatannya pun harus berbeda, begitu juga pendekatan pola pembangunannya.

Studi ini hendak meneliti tentang pola pembangunan yang diterapkan masyarakat pedesaan pesisir pantai sebagai upaya untuk mempertahankan kelangsungan dan kesejahteraan hidup mereka (survival). Di mana satu sisi masyarakat pesisir pantai (nelayan) merupakan masyarakat yang tergolong sebagai penduduk miskin dan terbelakang, yang belum tnencapai taraf hidup yang layak. ${ }^{2}$ Apalagi sejak krisis tahun 1998 sampai diterapkannya kenaikan harga BBM mulai persatu Maret 2005, mengisyaratkan rakyat yang paling menderita akibat kenaikan BBM tersebut adalah para petani dan nelayan, ${ }^{3}$ dan ketika BBM naik nelayan juga yang paling terpukul. ${ }^{4}$ Selain itu sebagian besar nelayan di Paciran dan Brondong, Lamongan, Jawa Timur, terpaksa menggunakan bahan bakar minyak oplosan, yakni minyak tanah dicampur oli untuk menghemat pengeluaran. ${ }^{5}$ Namun pada sisi lain mereka mampu survive dalam kehidupannya. Tidak hanya itu, di berbagai desa masyarakat nelayan ini menunjukkan kemajuan dan perkemabangan pembangunan masyarakat desanya. Indikasi ini bila dilihat mereka mampu menunjukkan dengan bukti beberapa berdirinya dan semakin berkembangnya sarana pembangunan, seperti bangunan Masjid-Masjid yang megah di lingkungannya, sarana gedung-gedung sekolah dan Madrasah-Madrasah yang ada, termasuk terlihat pada bangunan rumah mereka yang tergolong permanen dan pembangunan serta pemenuhan kebutuhan lainnya, termasuk pada pendidikan anak mereka dan kemampuan keahlian lainnya.

Nelayan yang kadangkala diposisikan hanya sebagai pekerja di laut, seringkali diopinikan clan dianggap tidak memiliki kemampuan yang signifikan dalam ikut mengisi pemberdayaan dan pembangunap bangsa, bahkan keraguan tentang keahlian nelayan yang sesungguhnya tidak dimiliki oleh masyarakat lain. Padahal keahlian spesifik dari nelayan ini merupakan keunggulan kooperatif yang dimiliki bangsa ini. Karena itulah,

\footnotetext{
2 R. Bintarto,1977, Geografi Desa. Yogyakarta: UP. Spring. Lihat juga Mubyarto dkk,1984, Nelayan dan Kemiskinan. Jakarta: Rajawali Press.

3 Radar Minggu, Edisi ke -93, 07-13 Maret 2005

4 Tempo Interaktif, Rabu 2 Maret 2005

5 Suara Pembaruan, Senin 07 Maret 2005 dan Indo Pos,06 Maret 2005
} 
masyarakat nelayan sebenarnya merupakan ikon utama keberhsilan pembangunan, khususnya kelautan. ${ }^{6}$

Menurut data Biro Pusat Statistik (BPS) tahun 2000, menunjukkan bahwa satu keluarga Indonesia rata-rata memiliki anggota keluarga 3,9 orang dengan pertumbuhan 2,87\% (Ha sil Sensus 2000 BPS). Meningkat pada tahun 2005 rata rata anggota keluarga sebesar 5 orang. Untuk rumah tangga katagori ini, dengan asumsi hidupnya sederhana (makan perkeluarga perhari Rp 25 ribu), untuk biaya makan saja perbulannya dibutuhkan sebesar Rp 750 ribu: listrik dan air menghabiskan Rp 75 ribu; dana untuk SPP anak Rp 30 ribu; transportasi anak sekolah jika perlu Rp 3000 perhari, maka perbulan (25 hari) memerlukan dana sebesar Rp 75 ribu. Sehingga kalau keperluannya hanya itu saja, maka minimal biaya bulanan yang harus ditanggung perkeluarga sebesar 930 ribu. Dengan asumsi persoalan sewa rumah (kalu ada), trasnsportasi, kesehatan, dan kebutuhan lainnya tidak termasuk hitungan ini.

Di lingkungan perairan di Indonesia pada dasarnya dapat dikatagorikan atas perairan laut yang sudah dikenal dengan nama laut nusantara dan perairan daratan. Di mana Indonesia merupakan negara kepulauan yang terdiri atas 13.000-an pulau, yang mempunyai garis pantai sepanjang $80.000 \mathrm{~km} .{ }^{7}$ Oleh karena itu tida.k mustahil jika di sekitar pesisir pantai muncul pemukiman-pemukiman penduduk.

Sebagaimana dengan lokasi dan kondisi fisiknya, pemukiman penduduk yang ada di sekitar pantai itu biasa dinamakan desa pantai atau pesisir pantai begitu juga lazimnya disebut masyarakat nelayan. Di mana kondisi keberadaan desa pesisir pantai yang ada ini merupakan sebuah proses sekaligus hasil pemahaman penduduk tentang lingkungannya dan akan berkembang di masa yang akan datang, Apalagi konsentrasi pembangunan Indonesia mendatang memiliki focus kepada kelautan sebagai potensi masa depan: Bersamaan dengan adanya perkembangan sebagai tuntutan kondisi jamannya yang merupakan proses yang mendesak dan terus menerus sebagai konsekuensi logis kebutuhan pembangunan, maka pada gilirannya akan mengenal corak ragam serta pola

\footnotetext{
${ }^{6}$ Priyanto Raharjo, 2002

7 Departemen P dan K, 1991, Kehidupan Masyarakat Nelayan di Muncar. Jakarta Dirjen Kebudayaan.
} 
pembangunan kehidupan sebagai hasil adaptasi penghuni masyarakat pesisir pantai secara aktif terhadap situasi dan kondisi lingkungan perairan dalam upaya untuk mempertahankan kelangsungan hidupnya (survival).

\section{Rumusan Masalah}

Berdasarkan uraian di atas permasalahan yang dirumuskan adalah bagaimana pola pembangunan dan nilai institusi sosial yang diterapkan untuk mempertahankan kelangsungan hidup masyarakat miskin pesisir pantai?

\section{Tujuan Penelitian}

Untuk mengetahui bagaimana pola pembarigunan dan nilai institusi sosial yang diterapkan untuk mempertahankan kelangsungan hidup masyarakat miskin pesisir pantai.

\section{Metode Penelitian}

Sesuai dengan tujuan penelitian ini, yaitu untuk melakukan penggambaran (deskriftifj dan pemahaman (under.standing) terhadap pola-pola pembangunan dan nilai institusi sosial masyarakat pesisir. Begitu juga untuk pengembangan dan penemuan (eksplanatif) terhadap model-model pola pembangunan yang relevan bagi masyarakat pesisir pantai serta perlunya penafsiran (interpretatif) terhadap nilai institusi sosial yang dianggap mendukung bagi upaya mempertahankan kelangsungan dan peningkatan kesejahteraan hidup masyarakat pesisir dalam latar penelitian ini, maka jenis penelitian ini menggunakan model penelitian kualitatif.

\section{HASIL DAN PEMBAHASAN}

\section{Problem Masyarakat Nelayan}

Kesulitan dalam upaya untuk meningkatnya kualitas kesejahteraan bagi masyarakat pesisir pantai nelayan Desa Weru, Paciran dan Blimbing setelah peneliti mendapatkan gambaran data yang telah dikumpulkan selama terjun di komunitas masyarakat tersebut paling tidak terdapat beberapa problem yang tengah dihadapi oleh masyarakat. Secara garis besar problem-problem yang ada selain dipengaruhi oleh faktor internal, juga karena faktor eksternal. Adapun problem-problem tersebut antara lain : 


\section{Semakin Terbatasnya Sumber daya Laut}

Kenyataan terhadap semakin menurunya hasil tangkapan para nelayan akhir-akhir ini disbanding dengan beberapa tahun yang lalu semakin dirasakan oleh masyarakat nelayan dari ketiga Desa. Walaupun 20-30 tahun yang lalu masyarakat nelayan menggunakan peralatan yang sederhana, perahu layar tanpa mesin seperti sekarang, peralatan alat tanngkap jaring yang serba terbatas dan jangkauan penangkapan tidak terlalu jauh bias menjanjikan hasil tangkapan yang melimpah bahkan ragam dan jenis ikan pun masih dirasa lengkap memenuhi kelengkapan habitat ekosistemya. Kenyataan ini terbukti bahwa setiap hasil tangkapan nelayan masih bias memenuhi standar minimal perolehan dengan kebutuhan pada masa lalu. Namun pada akhir-akhir ini terasa semakin sulit dan terbatas pendapatan dari hasil tangkapan para nelayan menjadi indikasi semakin terbatasnya kandungan isi laut. Sebagaimana hal ini diceritakan oleh beberapa nelayan, baik para nelayan Desa Weru, Paciran dan Blimbing.

Salah satu bukti yang kini dirasakan dan diceritakan oleh para nelayan Desa Weru misalnya terhadap tingkat perolehan pada musim ikan tertentu. Mereka menceritakan pada kurun sekitar tiga puluh tahun yang lalu misalnya ketika musim ikan layang (jenis ikan pindang) yang biasanya muncul pada sekitar bulan Agustus-Nopember selalu menjanjikan pada nelayan desa ini untuk memperoleh hasil tangkapan yang berlimpah atau masyarakat Desa ini menyebut Along, saking melimpahnya sampai musim ikan ini menjadi bulan panen bagi masyarakat baik Desa Weru dan Blimbing. Begitu juga pada kurun dulu ada yang mereka sebut musim nyerampat ${ }^{8}$ ) pada musim ini menunjukkan ramainya hsil panen tangkapan jenis ikan Tiwu atau Banyar begitu juga jenis ikan Mbelo sampai mencapai kwintalan bahkan satu perahu mendapatkan hasil berton-ton, namun sekarang hasil yang melimpah seperti itu jarang lagi didapatkan oleh para nelayan, padahal alat tangkapan jaman sekarang lebih modern dan lengkap ${ }^{9}$ ). Begitu juga seperti yang dituturkan oleh beberapa nelayan Paciran. Mereka mengisahkan bahwa Desa ini

\footnotetext{
8 ) Nyerampat adalah istilah pada masyarakat Desa Weru yang mengjelaskan arti pergi melaut lebig dari satu kali dalam sehari, bahkan sanpai berkali-kali dalam satu hari. Kondisi ini kkarena saking melimpahnya hasil tangkapan sekali masang jarring, sehingga hasil tangkapan yang banyak melebihi kapasitas muatan perahu ini harus dibawa pulang dulu, lalu kemudian berangkat melaut lagi. Hal ini menunjukkan bahwa hasil tangkapan para nelayan bias melebihi kapasitas muatan perahu saking melimpahnya hasil tangkapan.

9 ) Hasil wawancara dengan Bapak. Askan, Khudlori, Abdullah, Muktasit dan lainnya/beberapa nelayan Desa Weru, dan nelayan Desa Blimbing, Maret 2006
} 
dulu terkenal sebagai julukan sebagai nelayan Udang. Artinya masalah penagkapan jenis Udang apapun selalu dicirikan nelayan Paciranlah yang paling jago. Karena sejarah membiktikan bahwa memang hasil tangkapan jenis udang ini disamping melimpah, masyarakat nelayan setempat berkonsentrasi pada peralatan alat tangkap udang, dan mereka berkisah hasil tanggkapan dulu disbanding sekarang lebih jauh kemundurannya

$\left.{ }^{10}\right)$. Hal ini mengindikasikan bahwa habitat dan ekosistem udang semakin punah dan terbatas. Hal ini sebagai penyebab dari penurunya juga pendapatan bagi masyarakat nelayan akhir-akhir ini. Bahkan mereka, baik masyarakat nelayan Weru, Paciran dan Blimbing merasa sudah tidak seimbang antara hasil tangkapan dengan biaya operasional yang semakin tinggi. Sehingga menjadi beban masalah bagi masyarakat nelayan selama ini.

\section{Tekanan Struktur dan Eksploitatif}

Ketidakberdayaan masyarakat nelayan mewarnai pada hubungan antara nelayan miskin dengan nelayan kaya, antara nelayan dan pengusaha menjadi pemandangan yang nyaris tidak pernah terungkap dan bahkan hal ini dianggap takdir sosial yang secara diam-diam menjadi sederet problem bagi masyarakat nelayan.

Dari beberapa temuan data menunjukkan bahwa ternyata banyak para nelayan menghadapi persaingan yang diakibatkan adanya perbedaan tingkat kemajuan peralatan antara nelayan satu dengan nelayan lainnya. Bahkan hal ini sedikit memicu konflik di antara nelayan yang menggunakan alat tangkap mini trawl/paying dengan nelayan non paying. Begitu juga alat transportasi perahu dan peralatan lainnya juga mempengaruhi terhadap tingkat perolehan bagi masyarakat.

Selain hal di atas yang menjadi salah satu ketidakberdayaan nelayan adalah karena daya tawar hasil tangkapan pada pembeli/pengusaha. Hal ini karena diakibatkan banyak para nelayan karena keterbatasan dana operasional kemudian meminjam uang pada pengusaha setempat dengan bersyarat hasil tangkapannya harus dijual pada orang yang meminjami uang. Kanyataan ini sering para nelayan tidak bisa berdaya dalam hal

\footnotetext{
${ }^{10}$ ) Hasil wawancara dengan Bapak Ambi, Bapak Masruchi, Bapak Said nelayan Paciran, Maret 2006
} 
tawar menawar pada mekanisme pasar. Hal ini terjadi pada masyarakat nelayan Desa Weru, Paciran dan Blimbing ${ }^{11}$ ).

\section{Dukungan Teknologi Relatif Sederhana}

Dari hasil temuan menunjukkan baik masyarakat Nelayan Weru, Paciran dan Blimbing dalam hal usaha perikanan yang ditekuni penduduk desa ini sebagaian besar umumnya masih didominasi usaha berskala kecil. Disamping itu juga dukungan teknologi relative sederhana, begitu juga kasil pengelolahan hasil produksi masih bersifat rentan waktu. Namun dari hasil pendalaman hal ini juga memiliki alasan keterbatan modal dan dana yang dialami masyarakat nelayan. Sementara pelaksanaan Program Pemberdayaan Ekonomi Masyarakat Pesisir (PEMP) misalnya yang telah dirintis Departemen Kelautan dan Perikanan sejak tahun 2000 ternyata tidak berjalan sesuai dengan rencana. Hal ini dirasakan oleh sebagaian besar masyarakat nelayan ketiga desa tersebut. Dari hasil pendalaman dengan beberapa nelayan ternyata mereka tidak pernah mendapatkan bahkan sebagaian besar mereka tidak tahu. Apakah hal ini disebabkan oleh sebagain LSM yang tidak kridibel, lemahnya control Pemda terhadap pengelolaaan dana tersebut atau ada alas an lain. Tapi yang jelas dari hasil temuan mereka para nelayan belum pernah mendapatkan kesempatan program itu bahkan mereka belum mengetahui.

\section{Dipengaruhi Irama Musim}

Siklus alam sebagai bagian dari pergantian musim memiliki pengaruh secara tidak langsung terhadap nasib para nelayan. Dari musim yang ada sebagain besar biasanya dibagi antara musim panen laut dan musim paceklik. Disamping itu juga didal musim itu pun ada musim yang berkaitan dengan adanya jenis ikan tertentu yang ada/muncul. Di kalangan nelayan musim itu sering disebut adanya musim baratan dan musin timur. Nama ini diambil dari arah angina yang menandai musim itu berlaku. Pada musim baratan (angina barat) biasanya menjadi musim paceklik, disamping itu pada musim ini keadaan cuaca alam kurang bersahabat pada nelayan. Musim gelombang air laut besar dan angina kencang menjadikan alas an para nelayan tidak berani melaut. Kalau sebagian

\footnotetext{
11 ) Hasil wawancara dengan bebarapa nelayan Weru, Paciran, Blimbing (tidak mau disebut nama), Maret 2006.
} 
ada yang berani melaut itu pun hanya mereka yang memiliki perahu besar dan alat mesin yang siap. Begitu juga jangkauan wilayah penangkapan dipilih hanya jarak yang aman saja. Biasanya musim baratan ini terjadi pada sekitar bulan Desember-Januari. Sedangkan bulan berikutnya disebut musim timur. Hal ini juga memiliki andil pengaruh pada aktifitas nelayan sehingga menjadi salah satu factor yang ada.

\section{Keterbatasan Pengalaman dan Pendidikan}

Tingat keejahteraan masyarakat sering diidentikkan dengan tingkat pendidikan pada masyarakat tersebut. Logika ini walaupun belum menjadi kausal kebenaran akan tetapi diyakini memiliki kaitan yang signifikan. Dari temuan data yang ada masyarakat pesisir pantai pada obyek penelitian ini memberikan kesan masih relatifnya tingkat pendidikan. Hal ini terlihat pada sebagian besar masyarakat yang ada tidak tamat dan hanya tamat pendidikan dasar. Walupun di Desa Paciran terlihat cukup perihal tingkat pendidikannya. Akan tetapi sebagaian besar mengindikasikan keberadaan tingkat pendidikan pada masyarakat nelayan Desa Weru, Paciran dan Blimbing perlu mendapatkan perhatian peningkatan lagi.

\section{Model Penguatan Kesejahteraan Pembangunan}

\section{Pengelolaan dan Kesinambungan Sumber daya Laut}

Berbicara tentang upaya meningkatkan kesejahteraan dan keberdayaan masyarakat desa pantai atau pesisir, baik Desa Weru, Paciran dan Blimbing hakekatnya bukan hanya mencakup makna penting tentang pengelolaan sumber daya perikanan berorientasi pada kesinambungan sumber daya laut, akan tetapi menyangkut persoalan bagaimana upaya pemberdayaan masyarakat nelayan tersebut dapat dilakukan untuk menjamin para masyarakat nelayan sebagai pelaku ekonnomi rakyat ini memperoleh apa yang sebenarnya menjadi hak mereka, khususnya kesejahteraan dan taraf kehidupan yang layak.

Dari temuan data mengindikasikan bahwa pengalaman telah banyak mengajarkan bahwa program-program yang pernah ada tentang pemberdayaan masyarakat nelayan dilakukan hanya sekedar mengutamakan pertimbangan logika produksi atau ekadar mengejar peningkatan hasil tangkapan ikan atau omzet produksi industri kecil di sektor 
perikanan. Sehingga menurut peneliti tidak hanya nantinya mengabitkan terjadinya pengurasan sumber daya laut yang tidak terkontrol (over exploited), tetapi juga bisa menimbulkan dampak proses marginalisasi dan polarisasi yang semakin jelas. Logiga ini bisa saja kelompok buruh nelayan atau Bolo Simbatan dan buruh industri kecil di sektor perikanan serta kelompok nelayan tradisional yang tidak memiliki modal cukup, ditambah lagi tidak memiliki peralatan teknologi memadai mereka menjadi semakin tersingkirkan, bahkan tidak bisa dihindari akhirnya rawan menimbulkan konflik di antara para nelayan. Sebagaimana hal ini sering terjadi konflik antara kelompok nelayan yang menggunakan alat pukat harimau/mini trawl atau payang dengan kelompok nelayan yang tidak menggunakan alat tersebut. Dan ini sering menimbulkan ketegangan antara nelayan Weru yang sebagian memakai alat payang misalnya dengan nelayan Paciran dan sekitarnya. Ditanbah lagi Pemerintah sendiri belum berhasil mencari solusi atas pertikaian ini.

Selain alasan di atas, selama ini terkesan bahwa berbagai program pembangunan masyarakat nelayan atau perikanan yang dilakukan sering masih berkonsentrasi pada rekayasa yang sifatnya teknis produksi dan cenderung berorientasi ekspor. Dampak dari logika ini dalam banyak hal lebih menguntungkan pada nelayan yang memiliki modal besar dan aset produksi berlebih. Kebijakan pembangunan perikanan dan upaya pengembangan masyarakat nelayan yang ditekankan sering kurang memperhatikan karakteristik dan konteks sosiologi local masyarakat nelayan itu sendiri. Oleh karena itu model pembaerdayaan kedepan adalah bagaimana tidak sekedar berorientasi rekayasa teknis produksi dan semangat ekspor tapi menafikan potensi dan karakteristik local. Maka yang dibutuhkan model pembangunan dan pemberdayaan masyarakat nelayan bukan sekedar kesediaan melakukan instropeksi tetapi juga bagaimana merevitalisasi program pemberdayaan masyarakat nnelayan yang enar-benar berpihak kepada lapisan yang paling miskin. Dan Pemerintah harus menaruh kesediaan untuk memperhatiakan hal ini.

\section{Orientasi Hasil Produksi ke Pola Baru Efisiensi Proses Produksi}

Masyarakat nelayan, khususnya Weru, Paciran dan Blimbing ini ibarat pasien yang mengalami komplikasi penyakit, perangkap kemiskinan yang melanda kehidupan 
komunitas desa pantai yang sesungguhnya disebabkan faktor-faktor yang kompleks. Nammun demikian salah satu kekurangan pokok yang perlu diperhatikan dari berbagai upaya penaggulangan kemiskinan yang banyak dipraktikkan adalah bahwa mereka menjadi begitu memusatkan perhatian pada peningkatan kuantitas produksi atau hasil sehingga kebutuhan sistem prroduksi mendapat tempat lebih afdal dan nomor wahid dari pada kebutuhan investasi bagi masa depan. Untuk itu bagaimana model pembangunan dan pemberdayaan perlu untuk mengubah paradigma program pemberdayaan masyarakat nelayan Weru, Paciran dan Blimbing yang semula cenderung pada orientasi pada peningkatan hasil produksi saja ke pola baru berorientasi pada efisiensi proses produksi dan upaya pengembangan deversifikasi usaha.

\section{Meningkatkan Posisi Bargaining masyarakat Nelayan}

Sebagai modal penguatan pembangunan dan pemberdayaan masyarakat nelayan untuk memberdayakan kegiatan produktif atau ekonomi rakyat masyarakat nelayan adalah bagaimana meningkatkan posisi bargaining mereka terhadap segala bentuk eksploitasi dan kebijakan sikap superordinasi. Dalam hal ini prasyarat yang wajib dibutuhkan adalah selain berbagai kemudahan ekonomi ${ }^{12}$ ) yang benar-benar nyata, dan tidak kalah pentingnya adalah terciptanya peluang-peluang sosial yang memihak kepada pelaku ekonomi rakyat ${ }^{13}$ )

\section{Menghindarkan Ketergantungan sebagai Penyangga Sosial}

Untuk menhindari tumbuhnya ketergantungan yang dapat menghilangkan mekanisme self-help msyarakat di desa pesisir karena terlalu banyak dijejali prgram penanggulangan kemiskinan yang bersifat karitatif ke depan ada baiknya jika programprogram yang bertujuan memperkuat penyangga sosial-ekonomi keluarga-keluarga miskin di desa pantai lebih menekankan pada berfungsi sebagai asuransi sosial bagi

\footnotetext{
12 ) Yang dimaksud kemudahan ekonomi (economic facilities) adalah kesempatan dan makin terbukanya akses masyarakat di Desa pesisir pantai terhadap berbagai sumber permodalan dan pasar yang tidak dibayang-bayangi dengan syakwasangka yang sering mendeskriditkan masyarakat miskin nelayan.

13 ) Yang dimaksud peluang-peluang social adalah upaya untuk meningkatkan akses pelaku ekonomi rakyat di desa nelayan terhadap berbagai fasilitas dan kebutuhan dasar, seperti pendidikan, kesehatan, bahkan kebutuhan melakukan partisipasi politik secara aktif dan sehat.
} 
kelompok masyarakat yang membutuhkan. Yang maksud asuransi sosial di sini program bantuan yang bisa brmanfaat sebagimana penyangga kebutuhan warga masyarakat dalam jangka lebih panjang, dan bukan sekedar program darurat yang habis seketika untuk memenuhi kebutuhan sesaat.

Terlepas apakah dana bantuan yang dikucurkan atau digulirkan ke masyarakat pantai nanti akan diprioritaskan kepada kelompok nelayan atau pekerja industri kecil sektor perrikanan, yang terpenting dana bantuan itu diupayakan tidak habis seketika. Tetapi, menjadi semacam dana abadi yang terus berkembang dan berkembang dan dikembangkan dengan jaminan dan legstimasi dan norma-norma sosial yang berlaku di masyarakat setempat. Tujuan utama dari pengembangan program asuransi sosial ini untuk mengeliminasi kemungkinan masyarakat desa nelayan Weru, Paciran dan Blimbing diperlakukan salah oleh para tengkulak atau pengijon yang sering memanfaatkan kerentanan keluarga-keluarga miskin tatkala musim paceklik tiba (musim baratan). Dengan memiliki tabungan sendiri yang cukup atau dukungan asuransi sosial dari lingkungan sosialnya, diharapkan keluarga-keluarga miskin di desa pantai tidak akan lagi terlalu muda ditekan meskipun pada musim paceklik sekalipun. Tentang bentuk asuransi sosial yang dikembangkan nanti, bisa berupa koperasi simpan pinjam yang dikelola forum pengajian, lembaga keuangan mikro (LKM) yang dikelola Dasa Wisma, Baitul maal atau kantong-kantong ekonomi sosial yang dibentuk oleh kampung baik melalui lembaga agama (seperti Masjid) dan sebagainya.

Sekadar sebagai contoh yang berhasil dilakukan oleh masyarakat nelayan Desa Weru dalam meningkatkan pembangunan masyarakat dan bisa dikembangkan oleh Desa lainnya adalah sebagai berikut; Pengelolaan dana sosial yang disebut Kajaan, Sokongan dan Gentenan $^{14}$ ). Kajaan adalah bentuk pengumpulan dana pembangunan masyarakat

14 ) Kajaan adalah bentuk bantuan yang berupa pekerjaan melaut dan semua hasilnya bersama-sama diberikan kepada orang atau lembaga yang membutuhkan dengan setelah dikurangi biaya operasional. Biasanya kajaan ini dilakukan ketika ada hajatan, membangun tempat ibadah, tempat pendidikan dan acara-acara desa.

Sedangkan Sokongan adalah bantuan berupa barang dan uang untuk diberikan kepada yang membutuhkan. Biasanya dilakukan ketika ada salah seorang yang mendapat musibah, para fakir miskin, anak yatim, biasanya pada waktu menjelang puasa, saat hari raya idul fitri. Dan sokongan ini menjadi semajam kewajiban rutin yang dikelola melalui Baitul Maal.

Gentenan, adalah bentuk bantuan gotong royong para nelayan untuk saling berbagi dan bekerja sama dalam hal yang berkaitan dengan kenelayanan, misal ketika mengangkat perahu atau istilahnya nyurung perahu ke daratan atau ke tepi laut, serta dalam kebutuhan lainya. 
nelayan Desa Weru yang diperoleh dari para nelayan. Dana ini diambil satu kali pendapatan melaut setiap satu bulan sekali dari semua perahu dan nelayan yang ada di Desa Weru. Jadi setiap perahu wajib memberikann setoran hasil tangkapan seluruhnya satu bulan sekali setelah dikurangi biaya operasional. Pengumpulan dana bentuk ini dilakukan melalui koordinasi ketakmiran Masjid Desa. Adapun hasil yang terkumpul dipergunakan untuk biaya pembangunan desa, baik pembangunan fisik lembaga keagamaan seperti Masjid, lembaga pendidikan, biaya sekolah anak dan simpan pinjam bagi masyarakat yang membutuhkan. Dari pengalaman ini membuktikan bahwa pembangunan fisik baik Masjid-masjid dan lembaga pendidikan menjadi terasa nyata hasilnya. Sehingga tidak heran berdiri bangunan masjid, sekolah yang megah dan mewah. Disamping program itu ada lain seperti Iwak penimbang, Bazar Desa, rasionalisasi zakat dan sebagaimanya. Dan hal (pengelolaan) ini melibatkan aparat desa, tokoh masuyarakat, ulama dan para donatur dan penyumbang.

\section{Penutup}

Kesulitan meningkatkan kesejahteraan komunitas desa pantai, selain dipengaruhi faktor internal, juga karena pengaruh faktor eksternal. Keterbatasan pendidikan kurangnya kesempatan mengakses dan menguasai teknologi yang modern dan tak dimilikinya modal cukup adalah faktor-faktor internal yang sering menyulitkan usahausaha memberdayakan kehidupan para nelayan.

Disisi lain, sejumlah faktor eksternal, seperti makin terbatasanya potensi sumberdaya laut yang bisa dimanfaatkan nelayan, persaingan yang makin intensif, mekanisme pasar, posisi tawar nelayan, persaingan yang makin intensif, mekanisme pasar, posisi tawar nelayan dihadapan tengkulak keadaan infrastruktur pelabuhan perikanan, dan yurisdiksi daerah otonomi adalah beban tambahan yang makin memperparah tekanan kkemiskinan yang dihadapi masyrakat desa pesisir.

Upaya untuk meningkatkan kesejahteraan dan keberdayaan komunitas desa pantai atau pesisir sesungguhnya bukan hanya mencakup arti penting pengelolaan sumber daya perikanan (fisheries management) yang berorientasi pada kesinambungan sumber daya laut (sustai nability), tetapi juga menyangkut persoalan bagaimana upaya pemberdayaan 
masyarakat desa pesisir yang dilakukan dapat menjamin para pelaku ekonomi rakyat memperoleh apa yang sebetulnya menjadi hak mereka khususnya kesejahteraan dan taraf kehidupan layak.

Pengamalan dimasa lalu telah banyak mengajarkan bahwa program-program pemberdayaan masyarakat desa pesisir yang dilakukan hanya berdasarkan pertimbangan logika produksi atau sekadar mengejar peningkatan hasil tangkapan ikan atau ommzet produksi industri kecil di sektor perikanan, bukan saja menyebabkan terjadinya pengurasan sumber daya laut yang tak terkendali (over exploited), tetapi juga melahirkan proses marginalisasi dan polarisasi yang mmakin mencolok mata. Kelompok buruh nelayan dan buruh industri kecil di sektor perikanan serta nelayan tradisional yang tidak memiliki modal cukup ditambah pula tak memiliki modal cukup ditambah pula tak memiliki peralatan teknologi memadai mereka umumnya makin tersisih, rawan diperlakukan mobilitas vertikal karena struktur yang ada makin hari terasa tidak ramah.

Selama ini timbul kesan kuat bahwa berbagai program pembangunan perikanan yang di lakukan sering masih terkonsentrasi pada rekayasa yang sifatnya teknis produksi dan cenderung berorientasi ekspor, sehingga dalamm banyak hal lebih menguntungkan nelayan yang memiliki modal dan aset produksi berlebih. Kebijakan pembangunan perikanan dan upaya pengembangan komunitas desa pantai yang dikembangkan sering kurang memperhatikan ka rakteristik dan konteks lokal komunitas desa pantai, sehingga jangan heran jika yang terjadi kemudian adalah paket-paket kebijakan dan program yang bersifat meritokraktis. Mungkinkah kelompok pandega bisa meningkatkan kesejahteraannya jika paket-paket kebijakan dan program yang bersifat meritokratis. Mungkinkah kelompok pandega bisa meningkatkan kesejahteraannya jika paket-paket bantuan teknologi perikanan lebih diprioritaskan kepada nelayan pemilik atau juragan kapal yang dinilai lebih bisa diperca bakal tak menunggak cicilan pinjamannya?.

Untuk mencegah tidak lagi terperosok kekeliruan serupa, dan upaya pemberdayaan masyarakat di desa pantai benar-benar dapat berjalan efektif maka yang dibutuhkan bukan sekedar kesediaan melakukan intropeksi tetapi juga revitalisasi program pemberdayaan masyarakat pantai yang benar-benar berpihak kepada lapisan yang paling miskin. 
Dengan memahami kekurangan dan kelemahan komunitas di desa pantai, untuk lebih menjamin agar program pemberdayaan mamsyarakat di desa pantai benar-benar berjalan efektif, beberapa langkah strategis yang yang perrlu dilakukan dan dikembangkan.

Pertama, perlunya mengubah paradigma program pemberdayaan masyarakat pesisir yang semula condong lebih berorientasi yang semula condong lebih berorientasi pada peningkatan hasil produksi ke pola baru yang lebih berorientasi pada efisiensi proses produksi dan upaya pengembangan deversifikasi usaha. Masyarakat nelayan desa dimaksud bahwa ibarat pasien yang mengalami komplikasi penyakit, perangkap kemiskinan yang melanda kehidupan komunitas desa pantai yang sesungguhnya disebabkan faktor-faktor yang kompleks. Nammun demikian salah satu kekurangan pokok yang perlu diperhatikan dari berbagai upaya penaggulangan kemiskinan yang banyak dipraktikkan adalah bahwa mereka menjadi begitu memusatkan perhatian pada peningkatan kuantitas produksi atau hasil sehingga kebutuhan sistem produksi mendapat tempat lebih utama dari pada kebutuhan investasi bagi masa depan.

Kedua, untuk memberdayakan kegiatan produktif atau ekonomi rakyat masyarakat di desa pantai dan bagaimana meningkatkan posisi barganing mereka terhadap semua bentuk eksploitasi dan sikap superordinasi, tak pelak prasyarat yang di butuhkan selain berbagai kemudahan ekonomi (economic facilities) yang benar-benar nayata, yang tak kalah penting adalah terciptanya peluang-peluang sosial (social opportunities) yang memihak kepada pelaku ekonomi rakyat. Yang dimaksud kemudahan ekonomi, adalah kesempatan dan makin terbukanya akses masyarakat di desa pantai terhadap berbagai sumber permodalan dan pasar yang tidak dibayang-bayangi dengan syakwasangka yang sering mendiskredirkan masyarakat miskin. Sedang yang dimaksud peluang-peluang sosial adalah upaya uantuk emningkatkan akses pelaku ekonomi rakyat di desa pantai terhadap berbagai fasilitas dan kebutuhan dasar, seperti pendidikan, kesehatan, bahkan kebutuhan melakukan partisipasi politik secara aktif.

Ketiga, untuk menhindari tumbuhnya ketergantungan yang dapat menghilangkan mekanisme self-help msyarakat di desa pesisir karena terlalu banyak dijejali prgram penanggulangan kemiskinan yang bersifat karitatif ke depan ada baiknya jika programprogram yang bertujuan memperkuat penyangga sosial-ekonomi keluarga-keluarga 
miskin di desa pantai lebih menekan pada berfungsi sebagai asuransi sosial bagi kelompok masyarakat yang membutuhkan. Yang maksud asuransi sosial di sini program bantuan yang bisa brmanfaat sebagimana penyangga kebutuhan warga masyarakat dala mjangka lebih panjang, dan bukan sekedar progra darurat yang habis seketika untuk memenuhi kebutuhan sesaat.

Terlepas apakah dan bantuan yang dikucurkan atau digulirkan ke masyarakat keda pantai nanti akan di prioritaskan kepada kelompok nelayn atau pekerja industri kecil sektor perrikanan, yang terpenting dana bantuan itu diupayakan tidak habis seketika. Tetapi, menjadi semacam dana abadiyang terus berkembang dan berkembang dan dikembangkan dengan jaminan dan legistimasi dan norma-norma sosial yang berlaku di masyarakat setempat. Tujuan utama dari pengembangan program asuransi sosial ini untuk mengeliminasi kemungkinan masyarakat desa pantai diperlakukan salah oleh para tengkulak atau pengijon yang serring memanfaatkan kerentanan keluarga-keluarga miskin tatkala mmusim paceklik tiba. Dengan memiliki tabungan sendiri yang cukup atau dukungan asuransi sosial dari lingkungan sosialnya, diharapkan keluarga-keluarga miskin di desa pantai tidak akan lagi terlalu muda ditekan meski pada musim paceklik sekalipun. Tentang bentuk asuransi sosial yang dikembangkan nanti, bisa berupa koperasi simpan pinjam yang dikelola forum pengajian, lembaga keuangan mikro (LKM) yang dikelola Dasa Wisma, dan sebagainya. Seperti keberhasilan pada masyarakat nelayan Weru misalnya, melalui apa yang disebut Kajaan, Sokongan, Gentenan, Iwak Penimbang, Bazar Desa, Baitul Maal, Rasionalisasi Zakat shadaqah dan sebagainnya.

Di tengah tekanan situasi krisis dan belenggu perangkap kemiskinan kronis, harus diakui tidaklah mudah memberdayakan dan sekaligus meningkatkan kesejahteraan sosial masyarakat yang tinggal di wilayah desa pantai. Namun demikian, dengan menyadari program pemberdayaan yang dirancang sejak awal dan kemudian dilaksanakan benarbenar bertumpuh pada pranata lokal, berbasis pada komunitas setempat, serta menempatkan plelaku ekonomi rakyat itu sendiri sebagai subjek, niscaya hasil akhirnya akan lebih maksimal dan semoga ini menjadi pertimbangan dan rekomendasi bagi kepentingan pembangunan, khususnya bagi pembagnunan dan pemberdayaan masyarakat pesisir pantai dalam upaya untuk mempertahankan kehidupannya. 


\section{DAFTAR PUSTAKA}

Abiding, Zainal. 1979. Dasar-Dasar Ekonomi Islam. Jakarta: Bulan Bintang. Ahmadi, Abu. 1984. Pengantar Sosiologi. Solo: Ramadani.

Al Wa'ie, No. 55 tahun V, Maret 2005. Hal: 15.

Black, James A; Champion Dean J. 1999. Metode dan Masalah Penelitian Sosial. Bandung: Rafika Aditama.

Departemen Kelautan dan Perikanan RI, Info Aktual, 18 Januari 2005.

Departemen P dan K. 1991. Kehidupan Masyarakat Nelayan di Muncar. Jakarta Dirjen Kebudayaan.

Ensiklopedi Indonesia. 1983. Ictiar Baru Van Haeve dan Elsevier Publishing Projects. Jakarta.

Farhan, Hamim. 1993. Pelaksanaan Pendidikan Agama Islam di Lingkungan Masyarakat Nelayan Desa Weru, Kecamatan Paciran, Kabupaten Lamongan. Yogyakarta: LPM UII Press.

Hasil Sensus 2000 BPS, http://www.bps.go.id/sector/population. Didownload 18 Januari 2005.

Kalangil NS. 1993. Kebudayaan Minahasa, Dalam Buku Manusia dan Kebudayaan di Indonesia, Prof. Dr. Koencoroningrat. Jakarta: Djambatan.

Kompas, Sabtu 17 Mei 2005.

Mubyarto, Loekman Soetrisno, Michael Dove.1984. Nelayan dan Kemiskinan. Jakarta: Rajawali Press.

Pangemanan, Adrian P. 2002. Sumber Daya Manusia (SDM) Masyarakat Nelayan. http://rudyed.tripod.com/semI_023htm. Didownload 20/03/2005.

Radar Minggu, 07-13 Maret 2005.

Raharjo, Priyanto. 2000. Nelayan Nusantara Sebuah Falsafah Kehidupan. Makalah Falsafah Sains. Program Pascasarjana, IPB. http://rudyed.tripod.com/semI_023htm. Didownload 20/03/2005.

R. Bintarto. 1977. Geografi Desa. Yogyakarta: UP. Spring.

Sholihin, Ahmad, 2004. Mencermati Program Relokasi Nelayan. http://www.pikiran rakyat.com.cetak. Didownload 20/23/2005.

Soekamto, Soerjono, 1990. Sosiologi Suatu Pengantar. Jakarta: Rajawali Press.

Statistik Perikanan Indonesia dalam Angka 1992-1995. Departemen Pertanian, Direktorat Jenderal Perikanan Jakarta.

Suara Pembaharuan, Senin 7 Maret 2005.

Subyakto. 1984. Kebudayaan Ambon.

Suyanto, Bagong. 2003. Dalam Polemik Metodologis Memahami Masyarakt Nelayan di jawa Timur. Kompas 2005.

Suyanto, Bagong. 2003. Mencari Model Pemberdayaan Komunitas Desa Pantai. Surya, 10 September 2003.

Tarumengkeng, Rudy C. 2002. http://rudyed.tripod.com. Didownload 20/03/2005.

Tempo Interaktif, Rabu 2 Maret 2005. 